\title{
Modeling the chemical properties of sesame oil under the influence of pulsed electric field using the artificial neural networks
}

\author{
Amir ABDOLLAHI ${ }^{1}$, Masoud SHAFAFI ZENOOZIAN ${ }^{1,2}$, Mohammad Reza SAEIDIASL ${ }^{1}$, Mohammad \\ ARMIN $^{3}$, Adel BEIGBABAEI ${ }^{4}$
}

Received November 25, 2019; accepted May 01, 2020.

Delo je prispelo 25. novembra 2019, sprejeto 01. maja 2020.

\begin{abstract}
Modeling the chemical properties of sesame oil under the influence of pulsed electric field using the artificial neural networks

Abstract: In this study, PEF pretreatment was used to improve the efficiency of screw press method on the properties of extracted sesame seeds oil. Sesame seeds were treated at different PEF intensities $\left(250,3250\right.$ and $\left.6250 \mathrm{Vcm}^{-1}\right)$ and pulse numbers (10, 30 and 50). Then, the oil was extracted using a screw press at $33 \mathrm{rpm}$. Some physicochemical properties of the obtained oil including oil extraction efficiency, acidity index, determination of total phenolic compounds and activity of the inhibition of the DPPH free radical were evaluated. The results showed that the oil extraction efficiency initially increased at first but it showed reduction during PEF pretreatment at higher intensities. Increase in the applied PEF intensity and pulse number lead to an increase in the acidity and total phenolic compounds. While the oxidative stability of the oil reduced at the more intensive PEF conditions. However, the antioxidant activity was firstly increased and then decreased during PEF pretreatment. In addition, artificial neural network model was used to predict the effect of different PEF pretreatment conditions on the physicochemical properties of the extracted oil. The best model was the feed forward neural network with sigmoid hyperbolic tangent conduction function, Levenberg Marquardt training function with 5-6-2 topology.

Key words: sesame seeds oil extraction; pulsed electric field; artificial neural network model; physicochemical properties
\end{abstract}

Modeliranje kemijskih lastnosti sezamovega olja pod vplivom pulzirajočega električnega polja $\mathrm{z}$ uporabo umetnih nevronskih mrež

Izvleček: V raziskavi je bilo uporabljeno predhodno obravnavanje semen sezama s pulzirajočim električnim poljem (PEF) za izboljšanje učinkovitosti stiskanja in izboljšanje kakovosti olja. Semena sezama so bila izpostavljena različnim jakostim PEF $\left(250,3250\right.$ in $\left.6250 \mathrm{~V} \mathrm{~cm}^{-1}\right)$ in različnim številom pulzov (10, 30 in 50). Olje je bilo potem iztisnjeno pri $33 \mathrm{rpm}$. Ocenjene so bile nekatere fizikalno-kemične lastnosti dobljenega olja kot so učinkovitost ekstrakcije, indeks kislosti, vsebnost celokupnih fenolov in velikost inhibicije DPPH prostega radikala. Rezultati so pokazali, da se je učinkovitost ekstrakcije $\mathrm{v}$ začetku obravnavanja povečala, a se je potem zmanjševala $\mathrm{z}$ večanjem moči PEF. Povečanje moči PEF in števila pulzov je vodilo $\mathrm{k}$ povečanju kislosti in vsebnosti celokupnih fenolov. Pri tem se je oksidativna stabilnost olja zmanjšala v razmerah večje moči PEF. Antioksidativna aktivnost olja se je v začetku obravnavanja s PEF povečala in nato zmanjšala. Dodatno je bil za predvidevanje učinkov obravnavanja s PEF na fizikalno-kemijske lastnosti iztisnjenega olja uporabljen model umetne nevronske mreže. Najboljši model je bil dosežen z nevronsko mrežo s sigmoidno-hiperbolično funkcijo, in Levenberg Marquardtovo funkcijo učenja s 5-6-2 topologijo.

Ključne besede: ekstrakcija olja iz semen sezama; pulzirajoče električno polje; model umetne nevronske mreže; fizikalno-kemijske lastnosti olja

\footnotetext{
Islamic Azad University, Sabzevar Branch, Department of Food Science and Technology,Sabzevar,Islamic Republic of Iran

2 Corresponding author, e-mail: msafafi25@yahoo.com

3 Islamic Azad University, Sabzevar Branch, Sabzevar, Department of Agronomy, Islamic Republic of Iran

4 Research Institute of Food Science and Technology, Mashhad, Islamic Republic of Iran
} 


\section{INTRODUCTION}

Sesame seeds (Sesamum indicum L.) is cultivated in Asia and some parts of Africa particularly in Sudan, Nigeria and Ethiopia. The land under cultivation and the yield of sesame seeds were respectively 42.95 thousand hectare and 40.44 thousand tons in Iran during 2015 to 2016 (Abdollahi et al., 2018).The oil content of these seeds is ranged between $28 \%$ to $59 \%$ (Biabani \& Pakniyat, 2008). Sesame oil has pleasant flavor and aroma causing make it possible to be used as salad dressing and cooking oil. This oil is also used in preparing the shortening, margarine, cosmetics, perfume and drugs (Boselli et al., 2009). The sesame oil causes a decrease in human's blood pressure and cholesterol level due to containing phytosterols, tocopherols and lignans (Ogawa et al., 1995). This oil contains about $85 \%$ unsaturated fatty acids but it shows good stability against oxidative rancidity (Rostami et al., 2014). Sesame oil has been recognized for its healthpromoting properties, and more recently, studies have revealed that polyphenolic compounds found in sesame oil are responsible for its therapeutic effects (Jacklin et al., 2003). Among the compounds in sesame oil, sesamin is among the phenolic compound at the highest concentration. Ferulic acid, vanillic acid, syringic acid and gallic acid were of high content among phenolic compounds in sesame oil (Wu et al., 2016)

Cold press method is applied to produce the oil and press cake without using chemical materials; hence, the obtained oil and press cake are suitable for human consumption and herbivorous animals. Application of the cold press method shows some advantages such as low cost initial and operative investments, simplicity and wide range of production capacity (from low scale up to about 100 tons per hour). However, there is a high amount of oil residue (10-20\%) in the press cake. In this method, different factors such as press pressure, rotational speed of screw press, seed moisture content and process temperature influence the oil extraction efficiency. In addition, the control of seed moisture content and temperature are critical to prevent from the denaturation of press cake proteins (Azadmard-Damirchi et al., 2010) (Anderson et al., 1996).

Pulsed electric field (PEF) can been used as a pretreatment to enhance the efficiency of the oil extraction during screw pressing. In this method, the placed seeds (submerged in aqueous medium) between two electrodes are exposed to high voltage pulses (Asavasanti et al., 2011). The PEF process time is very short (about microsecond) and it can be performed at room temperature, which resulted to PEF known as a non-thermal method. The PEF technology prevents undesirable changes in physicochemical properties of the food so it shows advantages in comparison to the heating treatments (Pourzaki \& Mirzaee, 2009; Schroederetal., 2009).During PEF treatment, the microorganisms inactivation is achieved via electroporation phenomena (Quass, 1997). Electroporation is related to the effect of PEF on pore formation in the cell membrane. In fact, an external electric field creates a potential of additional membrane transfer that is more than natural potential of cell and when total potential of membrane reaches to the critical limit of about $1 \mathrm{~V}$, then tearing will occur. This membrane tearing can be irreversible or reversible. The reversible tearing is used in cell incitation, gene transfer and increase in metabolic activities of cell(Hamid Bakhshabadi et al., 2018). Low energy PEF treatment was successfully used to produce fat from micro-algae to lowering(La Choi et al., 2016). Researchers mentioned that PEF process conditions including applied intensity, frequency, pulse width and treatment time influenced the efficiency of oil extraction of sunflower seeds. They introduced the PEF treatment as effective method in the seeds oil extraction in large scales (Shorstkii et al., 2017).

The artificial neural network (ANN) is a simple simulated modeling method that is inspired by studying the living beings' mind and neural network system. High performance of biologic systems arising from nature is parallel to their neurons programming. An ANN performs this structure through distributing simulation in attached small and simple processor units (Fausett, 1994). ANN with input layer of three neurons (pressure, temperature and process time)was used to predict the efficiency of oil extraction from black caraway (output layer) using supercritical solvent method (Full ana et al., 2000). Nazari et al. (2015) used feed forward ANN to predict the oxidative stability of olive oil during storage time. Therefore, the aim of this study was to investigate the effect of PEF pretreatment condition (intensity and pulse numbers) on different physicochemical properties of the extracted sesame seeds oil. In addition, ANN modeling was used to predict efficiency of oil extraction from sesame seeds using PEF pretreatment.

\section{MATERIALS AND METHODS}

\subsection{MATERIALS AND EQUIPMENT}

The sesame seeds, containing $46.7 \%$ oil, was provided from local market of Ferdous town (Iran). At first, the external materials were separated and removed from the sesame seeds and then it was kept in resistant plastic bags against air and moisture penetration. The used equipment were laboratory sieve, grinding machine (Huddinge 14105, Sweden), Desiccator, laboratory oven 
(Memert, Germany), digital balance (Gec Avery, made in England), pulsed electric field machine (made in Food Industry Institute of Iran), Kjedahl device (Auto Analayser 130 Tecator CO) and oil extracting screw press (Kern Kraft, Germany).

\subsection{OIL EXTRACTION PROCESS}

The sesame seeds were pretreated at different PEF intensities $\left(250,3250,6250 \mathrm{~V} \mathrm{~cm}^{-1}\right)$ using various pulse numbers $(10,30$ and 50) according to Bakhshabadi et al.(2017) method. Then, the oil of PEF pretreated seeds was extracted using screw press with speed of $34 \mathrm{rpm}$.

\subsection{THE OIL EXTRACTION EFFICIENCY}

The percentage of oil extraction efficiency was calculated using Eq. 1. A digital balance with the precision of 0.01 was applied to weight the samples.

$$
\text { Oil extraction efficiency }(\%)=\frac{\text { mass of extracted oil }(g)}{\text { mass of initial seeds }(g)} \times 100
$$

\subsection{MEASUREMENT THE OIL ACIDITY}

The acidity of the oil was measured according to AOCS Cd 3-63 method (AOCS, 1993a).

\subsection{DETERMINATION OF OIL OXIDATIVE STA- BILITY}

According to AOCS Cd 12b-92 method, the oil stability against oxidation was determined using a Rancimat (AOCS, 1993b).This device works based on change in electric conduction of water existing in Rancimat container through compounds resulted from oxidative reaction of oil existed from device cell. In this study, the input airflow speed was set on 20 liter per hour.

\subsection{DETERMINATION OF THE CONTENT OFTO- TAL PHENOLIC COMPOUNDS}

The content of total phenolic compounds was determined using spectroscopy method. At first, $1 \mathrm{~g}$ of oil was mixed thoroughly with $3 \mathrm{ml}$ of methanol solution: water (90:10) for 4 minutes. Then, the solution was centrifuged at the $3000 \mathrm{rpm}$ for $5 \mathrm{~min}$. 20 micro liter of the obtained supernatant was mixed with water $(8.2 \mathrm{ml})$ and
Folin Ciocalteu reagent $(0.5 \mathrm{ml})$. After $5 \mathrm{~min}, 1 \mathrm{ml}$ of sodium carbonate $10 \%$ was added to the mixture and it was left in a dark place at the room temperature for 1 hour. Finally, the absorbance of the samples was recorded using a spectrophotometer at the wavelength equals to $765 \mathrm{~nm}$. Gallic Acid solution ( 0 to 1000 micro gram per $\mathrm{ml}$ ) was used to prepare the standard curve and the content of total phenolic compounds was reported as $\mathrm{mg}$ of gallic acid per kg of sample (Bail et al., 2008).

\subsection{THE ACTIVITY OF THE DPPH FREE RADI- CAL INHIBITION}

2-2-di-phenyl-1-picryl Hydrazine (DPPH), is a lipophilic radical showing the maximum absorption in $517 \mathrm{~nm}$ wavelength. The DPPH radicals react with antioxidants or other radicals resulting in decrease in their contents and absorption. Decrease in DPPH molecules has direct relation with available hydroxyl groups; and, the hydroxyl groups give hydrogen to the DPPH radicals and changed their color from dark violet to light yellow.

In this method, $1 \mathrm{ml}$ of $0.1 \mathrm{mM}$ methanol solution of DPPH was mixed completely with $1 \mathrm{ml}$ of extracted oil and was then placed in a dark place at the room temperature for $15 \mathrm{~min}$. The absorption of the mixture was read at $517 \mathrm{~nm}$ wavelength and percentage of DPPH free radical inhibition was calculated using Eq. 2 (Long et al., 2011).

$$
\text { Activity of the inhibition of the DPPH free radical }(\%)=\frac{A S-A C}{A C} \times 100
$$

Where AS and AC are optical absorption of sample and control, respectively.

\subsection{STATISTICAL ANALYSIS}

The response surface methodology using the Design-Expert version 6.0.2 was used to represent the graph of conditions of the PEF pretreatments (intensity and pulse number) on different physicochemical properties of the extracted oil. Finally, the neural network tool of MATLAB software was used to determine the optimum neural network. For the purpose of designing this network, two intakes of PEF intensities and pulse numbers were defined in a two-line matrix and the amount of oil extraction efficiency, acidity, oxidative stability, content of phenolic compounds and activity of the inhibition of the DPPH free radical were defined in a five-line matrix as outputs. Different neural networks contains activation functions and different learning and also the amount of different neurons in the hidden layer were designed. 
Then, their efficiency become distinguished using two criteria of evaluating the correlation coefficient $\left(\mathrm{R}^{2}\right)$ and mean squared error (MSE) using Eq. 3 and 4, respectively. At first, through examining the various neural networks, the feed forward neural network, with the highest efficiency was chosen. The amount of learning cycles were regarded 1000. Regarding these cases, different neural networks were designed in a manner containing a hidden layer with different number of neurons (1 to 10). To connect the input layer to the hidden layer, the hyperbolic, logarithm and linear sigmoid tangent activation functions were used in various test and error stages of networks. The linear activation function in the fixed form was also used to connect the hidden layer to the output layer. In addition to the mentioned cases two different learning patterns include Levenberg -Marquardt learning algorithm and resilient back propagation (trainrp) were used in different networks and their influence on the networks were evaluated.

$$
\begin{aligned}
& R^{2}=1-\frac{\sum_{i=1}^{N}\left(Y_{p i}-Y_{e i}\right)^{2}}{\sum_{i=1}^{N}\left(Y_{p i}-\overline{\mathrm{Y}}\right)^{2}} \\
& M S E=\frac{1}{N} \sum_{i=1}^{N}\left(\mathrm{Y}_{p i}-Y_{e i}\right)^{2}
\end{aligned}
$$

Where $Y_{p i}$ is the ratio of predicted features by the network $Y_{e i}$, is the ratio of features resulted from performing experiments and tests and $\bar{Y}$ is the mean of laboratory characteristics ratios and $\mathrm{N}$ is the total number of observations.

Entering the raw data will lead to a decrease in the speed and precision of network. Hence, to obtained acceptable and reliable results, it is necessary to normalize the en- tered data. In this study, the input and outputs were normalized between 0 and 1 using Eq. 5:

$$
\mathrm{V}_{\mathrm{N}}=\frac{\mathrm{V}_{\mathrm{R}}-\mathrm{V}_{\min }}{\mathrm{V}_{\max }-\mathrm{V}_{\min }}
$$

Where $\mathrm{V}_{\mathrm{N}}$ is the normalized data. $\mathrm{V}_{\mathrm{R}}$ represents the initial raw data. $\mathrm{V}_{\max }$ and $\mathrm{V}_{\min }$ are the maximum and minimum amounts of initial data, respectively.

\section{RESULTS AND DISCUSSION}

\subsection{EFFECT OF PEF PRETREATMENTCONDITIONS ON OIL EXTRACTION EFFICIENCY}

Fig. 1 represents the effect of PEF pretreatment conditions on the oil extraction efficiency. It was found that the applied pulse had no significant effect on this parameter $(p>0.05)$. However, the oil extraction efficiency was considerably affected by the applied PEF intensity $(p<0.05)$. During PEF pretreatment at higher intensities, the oil extraction efficiency initially increased due to the electrical degradation and permeability of the cells (Schroeder et al., 2009), but it then decreased as a result of further damage to the internal structure of the grains and closure of the oil outlets. The results are in agreement with Guderjan et al. (2005) findings.

\subsection{EFFECT OF PEF PRETREATMENT CONDI- TIONS ON OIL ACIDITY}

The PEF pretreatment significantly affected the oil acidity $(p<0.05)$ as shown in Fig. 2 . The increase in the acidity could be related to the rising in the lipase activity during

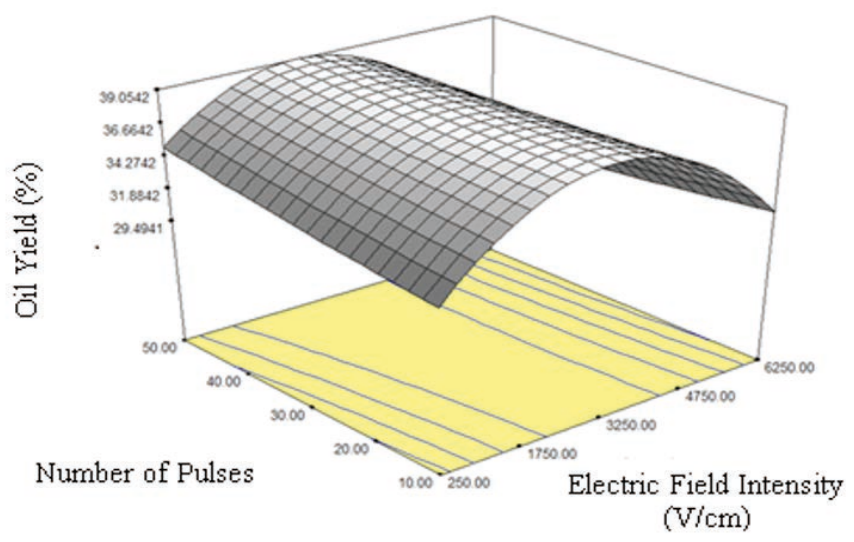

Figure 1: Effect of PEF intensity and pulse number on the oil extraction efficiency 


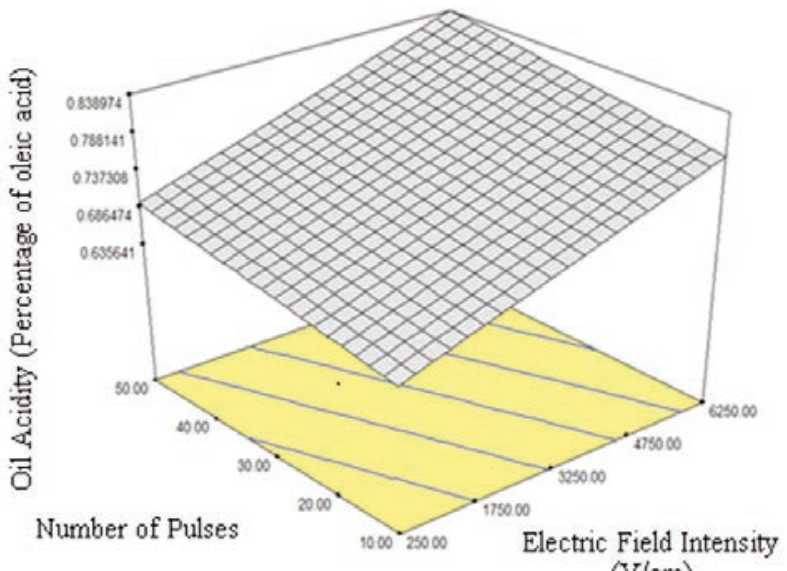

(V/cm)

Figure 2: Changes in oil acidity influence by the PEF pretreatment conditions

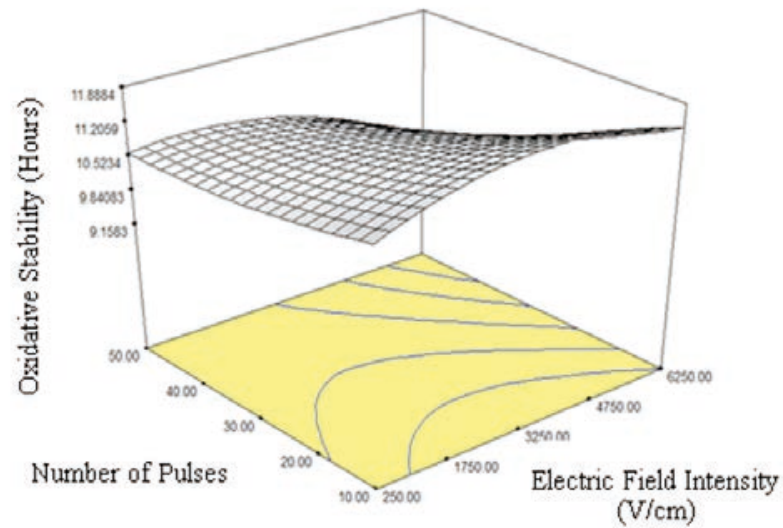

Figure 3: Influence of electric field intensity and pulse number on oil oxidative stability

PEF treatment; as, the activity of this enzyme resulted in production of free fatty acids which are undesirable constituents in edible oils (Guderjan et al., 2007). The same results were reported by Puértolas and de Marañón (2015) during studying the effect of PEF process on the olive oil properties.

\subsection{EFFECTOF PEF PRETREATMENT CONDI- TIONS ON OXIDATIVE STABILITY OF OIL}

Fig. 3 represents that the oxidative stability of oil decreased with increasing in the PEF intensity and number of pulses $(p<0.05)$. During PEF pretreatment, increase in free fatty acids content caused decrease in oxidative stability of the oil. However, the oil oxidative stability showed partial increase at the beginning of PEF process. The reason for the decrease in oxidative stability can be attributed to the increase in free fatty acids.

\subsection{EFFECT OF PEF PRETREATMENT CONDI- TIONS ON CONTENT OF TOTAL PHENOLIC COMPOUNDS}

The obtained results showed that the content of the total phenolic compounds influenced by the PEF pretreatment conditions $(p<0.05)$. The content of total phenolic compounds increased as the intensity of the electric field and the number of pulses increased (Fig. 4) as Sarkis et al. (2015) reported. This result could be attributed to the effect of PEF electroporation on release phenolic compounds into the oil (Boussetta et al., 2014).

\subsection{EFFECT OF PEF PRETREATMENT CONDI- TIONS ONANTIOXIDANTACTIVITY}

The PEF intensity and the pulse number had considerable effect on activity of the inhibition of the DPPH free 


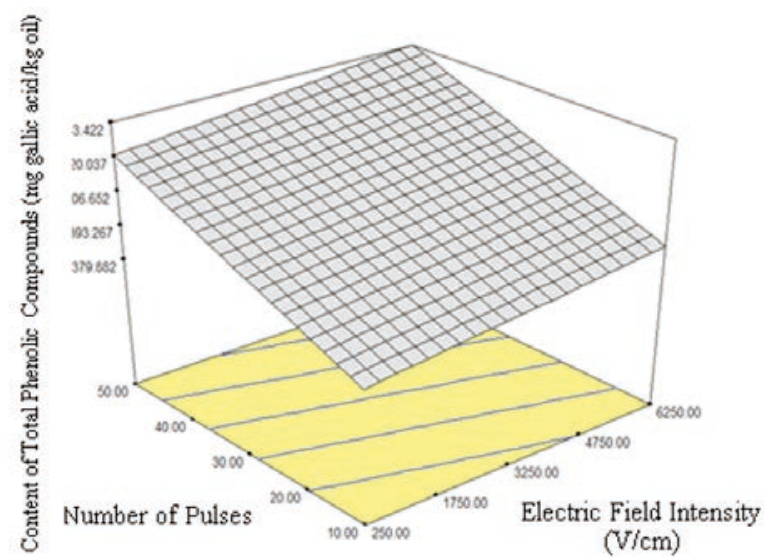

Figure 4: The alteration in the content of total phenolic compounds during PEF pretreatment

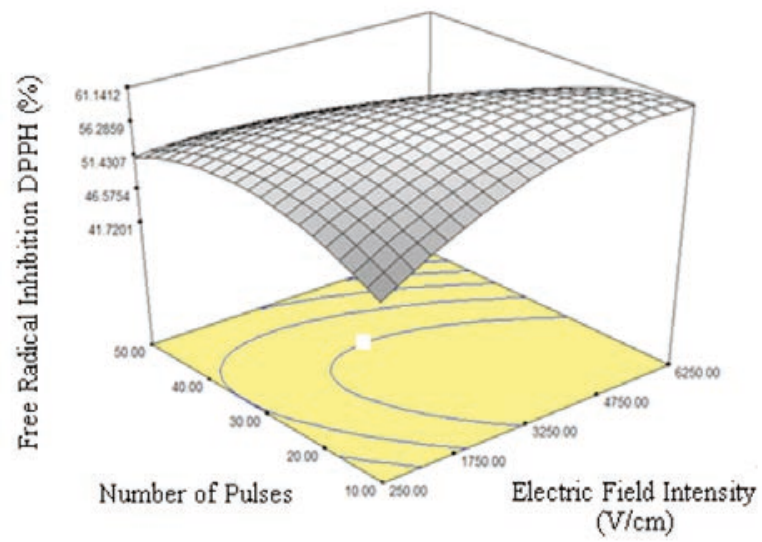

Figure 5: Effect of PEF intensity and pulse number on activity of the inhibition of the DPPH free radical

radical $(p<0.05)$. At low pulse numbers, the antioxidant activity enhanced by rise in the applied PEF intensity, but this trend reversed during pretreatment at high pulse numbers (Fig. 5). Electroporation phenomena causes the release of antioxidants such as tocopherols that result in higher activity of the inhibition of the DPPH free radical. In addition, the reduction in antioxidant activity can be also attributed to the destructive effect of higher PEF intensities on the chemical structures of antioxidants. These results were in agreement with the reports results by Guderjan et al. (2005).

\subsection{ARTIFICIAL NEURAL NETWORKS MOD- ELING}

Tables 1 to 3 represent comparison the effect of hidden layer neurons number and type of learning pattern on the prediction accuracy of the feed forward back propagation neural networks for using PEF pretreatment in sesame oil extraction with sigmoid hyperbolic tangent conduction function, logarithm and linear functions and learning cycle of 1000 , respectively.

The feed forward neural network with sigmoid hyperbolic tangent conduction function, Levenberg - Marquardt training function with topology of 2-6-5 (input layer with 2 neurons, a hidden layer with 6 neurons, and output layer with 5 neurons) was selected as the optimized neural network $\left(R^{2}=0.998\right.$ and MSE $\left.=0.00013\right)$. In addition, the high correlation coefficient of this optimized network against laboratory data for 5 regarded output variables shows high precision and accuracy of this model (Fig.6). However, the neural network has the least accuracy to measure the amount of oil oxidative stability in comparison to the studied parameters.

Fa and Okunola (2015) used methods of response surface and ANN to optimize the oil extraction from sesame seeds. The highest oil extraction efficiency (85.70 \%) 
Table 1: Comparison of the effect of hidden layer neurons number and type of learning function and sigmoid hyperbolic tangent activation function on accuracy and precision of predicting different characteristics of sesame oil extracted using PEF pretreatment

\begin{tabular}{|c|c|c|c|c|}
\hline \multirow[t]{2}{*}{ Neurons number } & \multirow[t]{2}{*}{$\mathrm{R}^{2}$} & \multirow[t]{2}{*}{ MSE } & Trainlm & trainrp \\
\hline & & & $\mathrm{R}^{2}$ & MSE \\
\hline 2 & 0.384 & 0.34809 & 0.899 & 0.00187 \\
\hline 3 & 0.984 & 0.00037 & 0.799 & 0.05649 \\
\hline 4 & 0.993 & 0.00191 & 0.962 & 0.00621 \\
\hline 5 & 0.924 & 0.00360 & 0.995 & 0.00477 \\
\hline$\underline{6}$ & $\underline{0.998}$ & $\underline{0.00013}$ & 0.996 & 0.00446 \\
\hline 7 & 0.997 & 0.00680 & 0.998 & 0.00399 \\
\hline 8 & 0.995 & 0.00891 & 0.997 & 0.00388 \\
\hline 9 & 0.997 & 0.00758 & 0.992 & 0.00551 \\
\hline 10 & 0.989 & 0.00689 & 0.997 & 0.00368 \\
\hline
\end{tabular}

Table 2: Comparison of the effect of hidden layer neurons number and type of learning function and sigmoid logarithm activation function on accuracy and precision of predicting different characteristics of sesame oil extracted using pulsed electric field pretreatment

\begin{tabular}{lllll}
\hline Neurons number & $\mathrm{R}^{2}$ & MSE & Trainlm & trainrp \\
\cline { 3 - 5 } & & & $\mathrm{R}^{2}$ & 0.799 \\
2 & 0.630 & 0.05789 & 0.00888 \\
3 & 0.734 & 0.01112 & 0.876 & 0.00658 \\
4 & 0.798 & 0.00999 & 0.877 & 0.00655 \\
5 & 0.810 & 0.00871 & 0.988 & 0.00498 \\
$\underline{6}$ & 0.819 & 0.00863 & 0.983 & 0.00782 \\
7 & 0.774 & 0.00998 & 0.991 & 0.00098 \\
8 & 0.899 & 0.00769 & 0.992 & 0.00099 \\
9 & 0.995 & 0.00177 & 0.992 & 0.00099 \\
10 & 0.887 & 0.00122 & 0.994 & 0.00089 \\
\hline
\end{tabular}

Table 3: The effect of hidden layer neurons number and type of learning function and linear activation function on accuracy and precision of predicting different characteristics of sesame oil extracted using pulsed electric field pretreatment

\begin{tabular}{|c|c|c|c|c|}
\hline \multirow[t]{2}{*}{ Neurons number } & \multirow[t]{2}{*}{$\mathrm{R}^{2}$} & \multirow[t]{2}{*}{ MSE } & \multirow{2}{*}{$\frac{\text { Trainlm }}{\mathrm{R}^{2}}$} & \multirow{2}{*}{$\begin{array}{l}\text { trainrp } \\
\text { MSE }\end{array}$} \\
\hline & & & & \\
\hline 2 & 0.677 & 0.054 & 0.698 & 0.04567 \\
\hline 3 & 0.783 & 0.041 & 0.881 & 0.04746 \\
\hline 4 & 0.794 & 0.0399 & 0.771 & 0.03671 \\
\hline 5 & 0.765 & 0.0296 & 0.698 & 0.02314 \\
\hline$\underline{6}$ & 0.766 & 0.0370 & 0.713 & 0.03670 \\
\hline 7 & 0.777 & 0.0429 & 0.715 & 0.03133 \\
\hline 8 & 0.775 & 0.0307 & 0.751 & 0.02415 \\
\hline 9 & 0.795 & 0.023 & 0.729 & 0.02648 \\
\hline 10 & 0.791 & 0.047 & 0.733 & 0.02354 \\
\hline
\end{tabular}


was obtained using neural networks; as, the mass of sesame samples, extraction time and solvent amount were $54.71 \mathrm{~g}, 44.88 \mathrm{~min}$ and $165.8 \mathrm{ml}$, respectively. Therefore, ANN was more effective in predicting the oil extraction process rather than the response surface method. They reported that regarding the complexity and multiplicity of effective factors in oil extraction particularly in industrial scale, ANN method can be introduced as an acceptable model for modeling these processes in industrial scales, too. ANN methods showed proper accuracy and precision in predicting the oxidation stability of canola oil with fatty acids in input layer and induction time in output layer (Dehghani et al., 2012). Przybylski and Zambiazi (2000)showed the high accuracy of applying ANN model in predicting the oxidative stability of vegetable oil when partial oil composition is known. A good predictability was obtained when composition of the major fatty acids and the amounts of tocopherols and tocotrienols were used with accelerated conditions, respectively.

As shown in Fig. 7, regarding the topology of selected ANN model (2-6-5), the weight matrix for the input layer to the hidden layer was a $2 \times 6$ referring to the connection of 2 input layer neurons to 6 hidden layer neurons (A matrix). The weight matrix for hidden layer to the output layer was a $6 \times 5$ (connection of 6 hidden layer neurons to 5 output layer neurons) representing as B matrix.

$A=\left(\begin{array}{cc}-7.73 & -3.14 \\ -5.42 & 5.57 \\ -6.96 & -2.97 \\ 1.67 & -0.17 \\ -0.69 & 0.66 \\ -5.09 & 8.76\end{array}\right)$

$\mathrm{B}=\left(\begin{array}{cccccc}5.11 & 5.77 & -2.83 & -0.06 & 2.99 & -5.02 \\ -4.13 & -16.56 & 2.62 & 5.73 & 14.29 & 6.53 \\ & & & & & \\ -37.05 & 40.27 & 3.05 & 6.15 & 16.35 & -25.67 \\ 2.63 & -8.38 & 1.10 & 1.59 & 0.25 & 5.28\end{array}\right)$

Meanwhile, bias matrixes for hidden layer (matrix C) and output layer (matrix D) were matrixes of $1 \times 6$ and $1 \times 5$.

It was determined that the efficiency of oil extraction and oxidative stability increased with an increase in

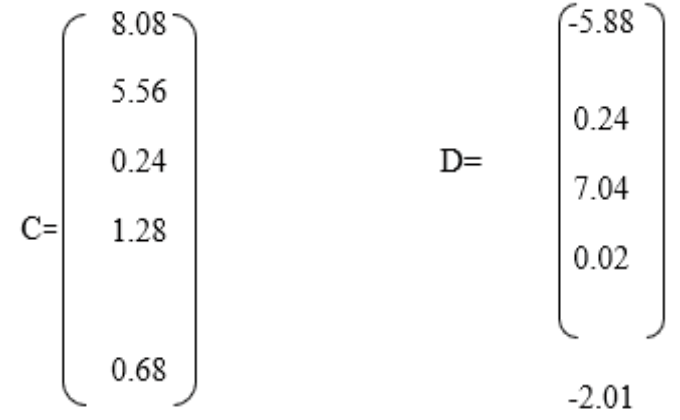

5.01

the applied PEF intensity. However, as higher pulse numbers were applied, the higher oil extraction efficiency and lower oxidative stability were observed. In addition, the oil acidity and the content of total phenolic compounds increased by rise in the applied PEF intensity and pulse numbers. However, it was found activity of the inhibition of the DPPH free radical was increased at first and decreased then during PEF pretreatment at higher intensity and pulse numbers.

\section{CONCLUSION}

In this study, PEF pretreatment was used to improve the effect of screw press method on the extracted sesame seeds oil properties. The obtained results revealed that the oil acidity and the content of the phenolic compounds increased during PEF pretreatment at higher intensity and pulse number. While the oxidative stability of the oil reduced at the more intensive PEF conditions. The oil extraction efficiency initially increased at first but it showed reduction during PEF pretreatment at higher intensities. At low pulse numbers, the antioxidant activity enhanced by rise in the applied PEF intensity, but this trend reversed during pretreatment at high pulse numbers. ANN model was used to predict the effect of different PEF pretreatment conditions on the physicochemical properties of the extracted oil. Considering the $\mathrm{R}^{2}$ and MSE, the feed forward neural network with sigmoid hyperbolic tangent conduction function, Levenberg - Marquardt training function with topology of 5-6-2 (input layer with 2 neurons, a hidden layer with 5 neurons, and output layer with 5 neurons) was selected as the most effective model. The high accuracy and precision of this model shows its effectiveness in optimizing and controlling the process conditions in order to produce the high quality oil as well as save time and energy. 


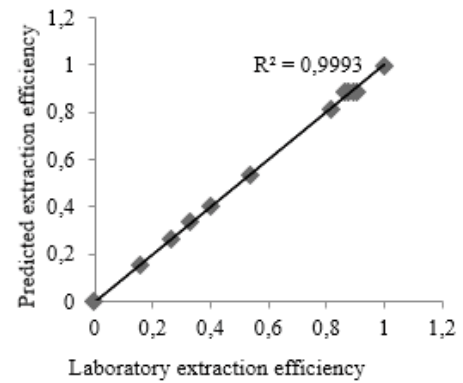

(a)

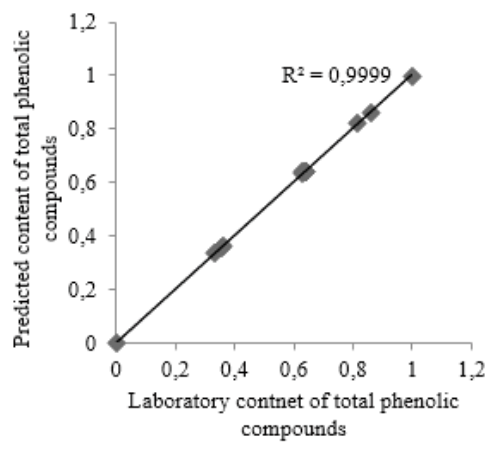

(c)

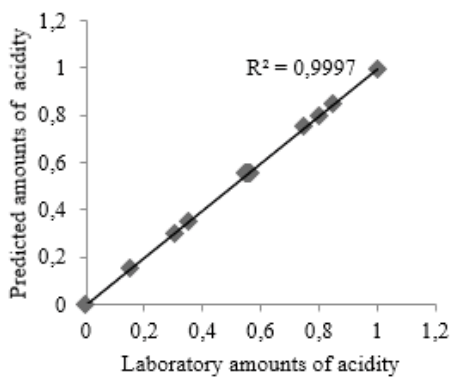

(b)

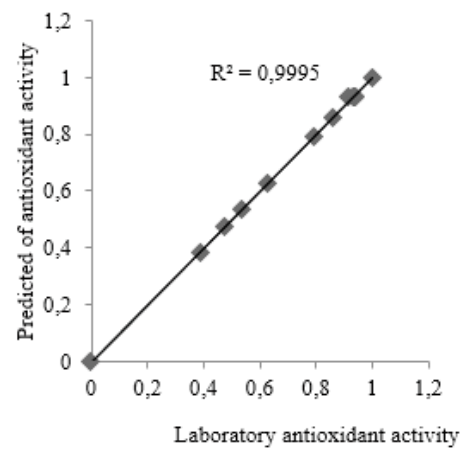

(d)

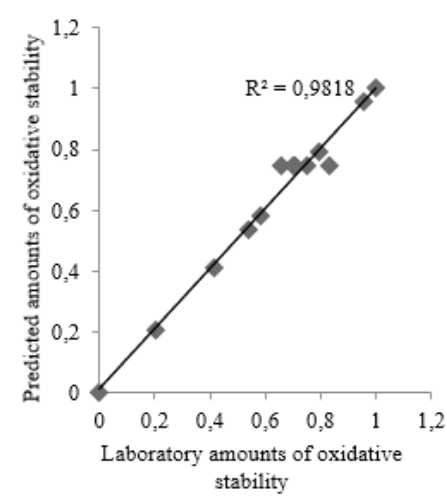

(e)

Figure 6: The predicted amounts of oil extraction efficiency (a), acidity (b), content of total phenolic compounds (c), antioxidant activity (d) and oxidative stability (e) using ANN model for optimized topology of (2-6-5) vs. laboratory amounts

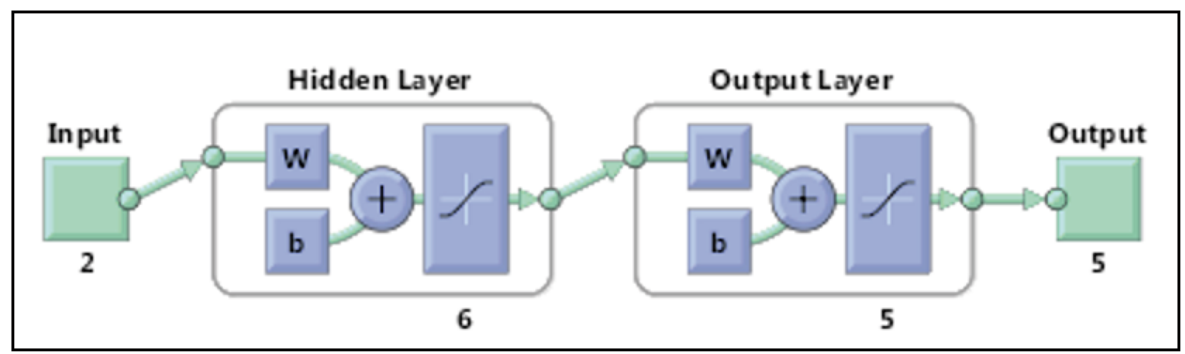

Figure 7: Schematic of different layers of the optimized ANN model with sigmoid hyperbolic tangent function using in predicting the effect of PEF pretreatment on oil properties 


\section{REFERENCES}

Abdollahi, A., Shafafi Zenoozian, M., Saeidi asl, M.R., Armin, M.,\& BeigBabaei, A. (2018). Modeling and predicting the process of changes in chemical properties of Sesame oil under the influence of Microwave using the artificial neural networks. Innovation in science and food technology,10(2), 13-21.

Anderson, D. (1996). A primer on oils processing technology. In: Y. H. Hui (Ed.), Bailey's industrial oil and fat products (pp. 10-17).New York, NY:JohnWiley and Sons.

AOCS. (1993a).Official Methods and Recommended Practices(American Oil Chemists' Society Method No. Cd 3-63). Retrieved from https://www.aocs. org/attain-lab-services/methods/methods/methoddetail? productId=111545.

AOCS. (1993b).Official Methods and Recommended Practices(American Oil Chemists' Society Method No. Cd 12b-92).Retrieved from https://www.aocs. org/attain-lab-services/methods/methods/methoddetail? productId=111524.

Asavasanti, S., Ristenpart, W., Stroeve, P., \& Barrett, D. M. (2011). Permeabilization of plant tissues by monopolar pulsed electric fields: effect of frequency. Journal of Food Science, 76(1), 98-111. https://doi.org/10.1111/j.17503841.2010.01940.x

Azadmard-Damirchi, S., Habibi-Nodeh, F., Hesari, J., Nemati, M. \& Achachlouei, B. F. (2010). Effect of pretreatment with microwaves on oxidative stability and nutraceuticals content of oil from rapeseed. Food Chemistry, 121(4), 12111215. https://doi.org/10.1016/j.foodchem.2010.02.006

Bail, S., Stuebiger, G., Krist, S., Unterweger, H., \& Buchbauer, G. (2008). Characterisation of various grape seed oils by volatile compounds, triacylglycerol composition, total phenols and antioxidant capacity. Food Chemistry, 108(3), 11221132. https://doi.org/10.1016/j.foodchem.2007.11.063

Bakhshabadi, H., Mirzaei, H., Ghodsvali, A., Jafari, S. M., Ziaiefar, A., \& Beigbabaie, E. (2017). The optimization of oil extraction of black cumin seeds with pulsed electric field pretreatment (PEF). Research and Innovation in Food Science and Technology (in Persian), 6(3), 221-234. https://doi. org/10.1002/fsn3.535

Bakhshabadi, H., Mirzaei, H., Ghodsvali, A., Jafari, S. M., \& Ziaiifar, A. M. (2018). The influence of pulsed electric fields and microwave pretreatments on some selected physicochemical properties of oil extracted from black cumin seed. Food science \& nutrition, 6(1), 111-118. https://doi. org/10.1002/fsn3.535

Biabani, A., \& Pakniyat, H. (2008). Evaluation of seed yieldrelated characters in sesame (Sesamum indicum L.) using factor and path analysis. Pakistan journal of biological sciences, 11(8), 1157-1160. https://doi.org/10.3923/ pjbs.2008.1157.1160

Boselli, E., Di Lecce, G., Strabbioli, R., Pieralisi, G., \& Frega, N. G. (2009). Are virgin olive oils obtained below $27^{\circ} \mathrm{C}$ better than those produced at higher temperatures?.LWTFood Science and Technology, 42(3), 748-757. https://doi. org/10.1016/j.lwt.2008.09.018

Boussetta, N., Soichi, E., Lanoiselle, J.L., \& Vorobiev, E. (2014).
Valorization of oilseed residues: extraction of polyphenols from flaxseed hulls by pulsed electric fields. Industrial crops and products, 52, 347-353. https://doi.org/10.1016/j.indcrop.2013.10.048

Dehghani, A. A., Mohammadi, Z. B., Maghsoudlou, Y., \& Mahoonak, A. S. (2012). Intelligent estimation of the canola oil stability using artificial neural networks. Food and bioprocess technology, 5(2), 533-540. https://doi.org/10.1007/ s11947-009-0314-8

Fa, A. T., \& Okunola, A. (2015). Modeling and Optimization of Extraction of Oil from Sesamum Indicum Seeds: A Case Study of Response Surface Methodology vs. Artificial Neural Network. International Journal of Chemistry and Materials Research, 3(2), 41-52. https://doi.org/10.18488/journal.64/2015.3.2/64.2.41.52

Fausett, L. (1994). Fundamentals of neural networks: architectures, algorithms, and applications. New Jersey, NJ: Prentice Hall.

Fullana, M., Trabelsi, F., \& Recasens, F. (2000). Use of neural net computing for statistical and kinetic modelling and simulation of supercritical fluid extractors. Chemical Engineering Science, 55(1), 79-95. https://doi.org/10.1016/S00092509(99)00182-7

Guderjan, M., Elez-Martínez, P., \& Knorr, D. (2007). Application of pulsed electric fields at oil yield and content of functional food ingredients at the production of rapeseed oil. Innovative Food Science \& Emerging Technologies, 8(1), 55-62. https://doi.org/10.1016/j.ifset.2006.07.001

Guderjan, M., Töpfl, S., Angersbach, A., \& Knorr, D. (2005). Impact of pulsed electric field treatment on the recovery and quality of plant oils. Journal of Food Engineering, 67(3), 281-287. https://doi.org/10.1016/j.jfoodeng.2004.04.029

Jacklin, A., Ratledge, C., Welham, K., Bilko, D., \& Newton, C. J. (2003). The sesame seed oil constituent, sesamol, induces growth arrest and apoptosis of cancer and cardiovascular cells. Annals of the New York Academy of Sciences, 1010, 374-380. https://doi.org/10.1196/annals.1299.068

La, H.J., Choi, G.G., Cho, C., Seo, S.H., Srivastava, A., Jo, B.H.,... Oh, H.M. (2016). Increased lipid productivity of Acutodesmus dimorphus using optimized pulsed electric field. Journal of applied phycology, 28(2), 931-938. https://doi. org/10.1007/s10811-015-0674-6

Long, J.J., Fu, Y. J., Zu, Y.G., Li, J., Wang, W., Gu, C. B., \& Luo, M. (2011). Ultrasound-assisted extraction of flaxseed oil using immobilized enzymes. Bioresource technology, 102(21), 9991-9996. https://doi.org/10.1016/j.biortech.2011.07.104

Nazari, R., Arabameri, M., \& Nouri, L. (2015). Modeling and predicting the oxidative stability of olive oil during the storage time at ambient conditions using artificial neural network. Iranian Journal of Nutrition Sciences \& Food Technology, 10(1), 71-80.

Ogawa, H., Sasagawa, S., Murakami, T.,\& Yoshizumi, H. (1995). Sesame lignans modulate cholesterol metabolism in the stroke-prone spontaneously hypertensive rat. Pharmacology Physiology Supplement, 1, 10-12. https://doi. org/10.1111/j.1440-1681.1995.tb02932.x

Pourzaki, A., \& Mirzaee, H. (2009). New high voltage pulse generators. Recent Patents on Electric Engineering, 2(1), 6576. https://doi.org/10.2174/1874476110902010065 
Przybylski, R., \& Zambiazi, R. C. (2000). Predicting oxidative stability of vegetable oils using neural network system and endogenous oil components. Journal of the American Oil Chemists' Society, 77(9), 925. https://doi.org/10.1007/ s11746-000-0146-x

Puértolas, E., \& de Marañón, I. M. (2015). Olive oil pilot-production assisted by pulsed electric field: impact on extraction yield, chemical parameters and sensory properties. Food Chemistry, 167, 497-502. https://doi.org/10.1016/j. foodchem.2014.07.029

Quass, D. (1997). Pulsed electric field processing in the food industry. a Status Report on PEF, Electric Power Research Institute, Palo Alto, CA, CR-109742.

Rostami, M., Farzaneh, V., Boujmehrani, A., Mohammadi, M., \& Bakhshabadi, H. (2014). Optimizing the extraction process of sesame seed's oil using response surface method on the industrial scale. Industrial crops and products, 58, 160165. https://doi.org/10.1016/j.indcrop.2014.04.015

Sarkis, J. R., Boussetta, N., Tessaro, I. C., Marczak, L. D. F., \& Vorobiev, E. (2015). Application of pulsed electric fields and high voltage electrical discharges for oil extraction from sesame seeds. Journal of Food Engineering, 153, 20-27. https://doi.org/10.1016/j.jfoodeng.2014.12.003

Schroeder, S., Buckow, R.,\& Knoerzer, K. (2009). NumericalSimulation of Pulsed Electric Field (PEF) Processing for Chamber Design and Optimization. InternationalConference on CFD in the Minerads and Process Industries CSIRO, 17 th, Australia.

Shorstkii, I., Mirshekarloo, M., \& Koshevoy, E. (2017). Application of pulsed electric field for oil extraction from sunflower seeds: electrical parameter effects on oil yield. Food Process Engineering, 40(1), e12281.https://doi.org/10.1111/ jfpe.12281

Wu, R., Ma, F., Zhang, L., Li, P.,Li, G., Zhang, Q., ... Wang, X. (2016).Simultaneous determination of phenolic compounds in sesame oil using LC-MS/MS combined with magnetic carboxylated multi-walled carbon nanotubes. Food Chemistry, 204, 334-342. https://doi.org/10.1016/j. foodchem.2016.02.086 